I received in the autumn of 1916 this peculiar form through the kindness of Mr. M. L. de Vilmorin. He sent me three specimens. One which I regard as the type had been collected in his Fruticetum (Les Barres) on Sept. 21, 1910 ("no. 1008 Y, Berberis du 30.3.05"). It has almost ripe fruits. The second specimen was collected on May 10, 1908 ("Berberis du 30 Mars 1905 ”); a flowering specimen of the fruiting plant. The third is sterile, collected on Sept. 13, 1916 ("Berberis from Verrières, ? Garden origin”).

This form represents apparently a cross between the evergreen $B$. pruinosa Franch., and the deciduous $B$. diaphana Maxim. In its angular twigs, slightly dentate leaves, and in its numerous ovules this hybrid comes nearer $B$. diaphana, but the less veined leaves, the apparently more vigorous growth, the more robust spines, the smaller flowers and the fruits clearly indicate the influence of B. pruinosa From the Kew Arboretum I saw a specimen collected in October, 1916 and bearing the name $B$. vulgaris divaricata that looks much like this hybrid. I wish to name this form in honor of the late Mr. Maurice L. de Vilmorin to whom I am under such great obligations for all the assistance he has given me during my dendrological studies.

Berlin-Dahlem, June, 1923. 


\section{THE HORTENSIAS \\ HYDRANGEA MACROPHYLLA DC. AND HYDRANGEA SERRATA DC.}

\section{ERnest H. Wilson}

The flower-loving peoples of China and Japan have cultivated in their gardens from time immemorial a number of plants beautiful for their flowers, foliage, or habit of growth. In the early intercourse of western nations with the Orient it was these that were carried to Europe and many of them have become the most familiar and most prized of our garden plants. The origin of many of these plants is still obscure, though in recent years several have been discovered growing wild in the interior parts of China and Japan. During the twenty years which I have devoted largely to the investigation of the flora of eastern Asia I have taken much interest in the problem of these long-cultivated plants. It has been my good fortune to elucidate the origin of a number including the China Monthly Rose, the Tea Rose, several Azaleas, the Chinese Pear, Apple, Cherry and others including the subject of this note.

There is no more familiar plant in the gardens and greenhouses of this country and of Europe than the so-called Hortensias. These Hydrangeas have been long cultivated in the West and in the hands of the plantbreeders, principally those of France, have given rise to a wonderfully varied group of valuable decorative plants. It was Thunberg, in 1784, who gave the first binominal names to these Hydrangeas but he referred them wrongly to the genus Viburnum. Other botanists at later dates have given them other names. To clear up the synonymy it was necessary to know exactly what the plants were that Thunberg named in his Flora Japonica. In order to accomplish this I wrote to Professor H. O. Juel at Upsala who most courteously had made a set of fine photographic prints of 'Thunberg's specimens. The material in Thunberg's herbarium consists of these seven specimens:

Viburnum macrophyllum $\alpha$. $=$ Hydrangea macrophylla DC.

Viburnum macrophyllum $\beta$. = Hydrangea macrophylla DC.

Viburnum serratum $\alpha_{\text {. }}=$ Hydrangea serrata var. stellata Wils.

Viburnum serratum $\beta$. = Hydrangea macrophylla DC.

Viburnum serratum $\gamma_{\text {. }}=$ Hydrangea serrata DC.

Viburnum serratum $\delta$. = Hydrangea serrata DC.

Viburnum serratum $\varepsilon$. = Hydrangea serrata DC.

The first-named, Viburnum macrophyllum, is the familiar Hydrangea with fleshy, shining green leaves and globose heads of pink, blue or white sterile flowers, variously known as $\boldsymbol{H}$. opuloides $\mathrm{K}$. Koch, $\boldsymbol{H}$. hortensis Smith, H. Hortensia Sieb. and so forth. The second, Viburnum serratum, is the Hydrangea with dull green thinner leaves and more slender shoots which is hardier than the former. Of this, too, there are many garden forms cultivated. 
Hydrangea macrophylla De Candolle, Prodr. Iv. 15 (1830).

Viburnum macrophyllum Thunberg, Fl. Jap. 125 (1784).

Hortensia Commerson apud Jussieu, Gen. Pl. 214 (1789)

Hortensia opuloides Lamarck, Encycl. Méth. III. 136 (1789); Tab. Encycl. Méth. II. 501, t. 380 (1793).-Jacquin, Fragm. Bot. 7, t. 3, fig. 5 (1800).Jaume in Nouv. Duhamel, III. 98, t. 24 (1806).

Primula mutabilis Loureiro, Fl. Cochinch. 104 (1790).

Hortensia japonica Gmelin in Linnaeus, Syst. Nat. ed. 13, II. pt. 1, 722 (1791).Buchoz, Monog. Ros. 267 (1804).

Hydrangea hortensis Smith, Icon. Pict. Pl., t. 12 (1792).-Sims in Bot. Mag. XıIr. t. 438 (1799).-Willdenow, Sp. Pl. II. pt. 1, 633 (1799).--Roth, Neue Beytr. Bot. 202 (1802).-Martius, Pl. Hort. Acad. Erlang. 98 (1814).-Savi, Fl. Ital. III. 65, t. 110 (1824).-Franchet \& Savatier, Enum. Pl. Jap. I. 150 (1875).-Nicholson, Dict. Gard. II. 162, fig. 252 (1887).--Rehder in Bailey, Cycl. Am. Hort. II. 784 (1900).--Bean, Trees \& Shrubs Brit. Isl. I. 625 (1914).- Turner in Gard. Chron. ser. 3, Lxxi. 87, fig. 42 (1922).

Hortensia mutabilis Schneevoogt, Icon. Pl. Rar. 36, t. (1793). -Zorn, Auswahl Schön. Gew. III. t. 149 (1796).

Hortensia japonica Zorn, Auswahl Schön. Gew. III. 58 (1796).

Hortensia rosea Desfontaines, Tab. Ecol. Bot. 115 (1804).

Hortensia speciosa Persoon, Syn. I. 505 (1805).-Targioni-Tozzetti in Ann. Imp. Mus. Firenze, I. (Obs. Bot.) 36, t. 2, figs. 51-58, 61, 63, 65-69 (1808).

Hydrangea Hortensia Siebold in Nov. Act. Acad. Leop.-Carol. xIv. pt. 2, 688 (Syn. Hydrang.) (1829).-De Candolle, Prodr. Iv. 15 (1830).-Maximowicz in Mém. Acad. Sci. St. Pétersb., sér. 7, x. no. xvi. 11 (Rev. Hydrang. As. Or.) (1867).--Hemsley in Garden, viII. 145 (1875); x. 265 (1876).

Hydrangea opuloides Hort. apud Savi, Fl. Ital. III. 65 (1824), as a synonym.K. Koch, Dendr. I. 353 (1869).-Koehne, Dendrol. 187 (1893).--Dippel, Handb. Laubholzk. III. 321 (1893).-Schneider, Ill. Handb. Laubholzk. I. 391, fig. 251 e -i (1905).--Rehder in Sargent, Pl. Wilson. I. 37 (1911); in Bailey, Stand. Cycl. Hort. III. 162 (1915).-Matsumura, Ind. Pl. Jap. II. pt. 2, 179 (1912).

Hyarangea Hortensia $\gamma$. flore pleno K. Koch, Hort. Dendr. 106 (1853).

Hydrangea japonica $\eta$. plena Regel in Gartenfl. xv. 290 (1866).

Hydrangea japonica $\eta$. Hortensia Regel in Gartenfl. xv. 290 (1866).

Hydrangea Hortensia є. Hortensia Maximowicz in Mém. Acad. Sci. St. Pétersb., sér. 7, x. no. xvi. 14 (Rev. Hydrang. As. Or.) (1867).

Hydrangea Hortensis 2. hortensia Franchet \& Savatier, Enum. Pl. Jap. I. 152 (1875).--Rehder in Bailey, Cycl. Am. Hort. Ir. 785 (1900).

Hydrangea Hortensia e. communis Hemsley in Garden, X. 266 (1876).

Hydrangea opuloides a. Hortensia Dippel, Handb. Laubholzk. III. 322 (1893).Rehder in Sargent, Pl. Wilson. I. 37 (1911); in Bailey, Stand. Cycl. Hort. III. 1621 (1915).-Matsumura, Ind. Pl. Jap. II. pt. 2, 180 (1912).

Hydrangea opuloides var. plena Rehder in Bailey, Stand. Cycl. Hort. III. 1621 (1915).

China; cultivated. Kwangtung, Honan Island, C. O. Levine, No. 849, May 18, 1917; Hupeh, Ichang, A. Henry, No. 7385; Yunnan, Tali Valley, alt. 6700-8000 ft., G. Forrest, No. 5047, August, 1906.

A shrub with many ascending-spreading stems forming a broad, rounded bush from 1 to $4 \mathrm{~m}$. tall, the shoots with abundant pith, clothed with thin, purple-gray to pale gray scaling bark, terete, glabrous, except near inflorescence, with prominent lenticels and leaf-scars. Leaves petiolate, lustrous green, fleshy, subcoriaceous, obovate, rarely ovate or ovateelliptic, 8-20 cm. long, $4-10 \mathrm{~cm}$. wide, cuspidate or short acuminate, at base cuneate, often broadly so, dentate-serrate, except near base; teeth inclined forward, triangular, terminating in a mucro-like gland, glabrous or slightly puberulous, with occasional axillary tufts of short, curled hairs; 
secondary veins arcuate, raised beneath; petiole stout, fleshy, $1.5-6 \mathrm{~cm}$. long, glabrous, flattened above. Inflorescence a much-branched, corymbose, terminal globose head from $15-20 \mathrm{~cm}$. and more through, either subsessile or distinctly peduncled, rhachis glabrescent, puberulous or more or less densely clothed with short gray appressed curled hairs; flowers pink to blue, sometimes white, sterile, with 4 spreading petaloid sepals of various size and shape, acute or rounded, entire or notched with few scattered male or apetalous abortive female flowers.

This is the familiar Hydrangea with globose heads of sterile flowers of varying shades of pink and blue. One of the most widely cultivated and best-known exotic plants. It has been cultivated for centuries in the Orient, yet its origin has escaped notice and remained unknown until now. It is simply an anomalous condition of a littoral plant very common on the shores of the Boshu peninsula in central Hondo, on Oshima or De Vries' Island, on Hachijo and others of the seven isles of Idzu, described in detail below under the name of $H$. macrophylla var. normalis. Where it originated or by whom it was first found and brought into gardens remains a mystery. Very likely it was by some wandering Buddhist priest or acolyte but we shall probably never know. That such a striking plant with splendid flower-heads should spread far and wide among the flowerloving peoples of the Orient should occasion no surprise. Where any remarks on its possible origin have been made in western literature China has been surmised as its native country, probably because so many fine plants have come to us from that land. In this case, however, the credit belongs to Japan.

The replacing of the ordinary flowers by sterile flowers having petaloid sepals occurs in several species of Hydrangea. It is found in the Japanese $H$. paniculata Sieb. and in the American $H$. cinerea Small and $H$. arborescens Linn. In China I have collected wild specimens of $H$. strigosa Rehd. with globose heads of neuter flowers. It is probable that this character can and does appear as a sport in many species of Hydrangea. Also it occurs in several species of Viburnum, and Thunberg doubtless had in mind the sterile form of Viburnum Opulus Linn. when he referred this Japanese plant to the genus Viburnım. Thunberg's description is quite clear and De Caridolle without hesitation refers it to the genus Hydrangea but does not suspect its identity with $H$. Hortensia Sieb. which he had described on the same page in his Prodromus. The most remarkable thing, however, about its name is the fact that, though many authors have dealt with the plant and several specific names have been established in common usage for it, apparently no one has gone to the trouble of finding out what Thunberg's Viburnum macrophyllum really was. For many years the problem of the origin of this plant has greatly interested me. In fact, during all my travels in the Orient I was on the look-out for the wild parent. Yet its discovery in March, 1917, was as surprising as it was welcome. The evidence was plain and conclusive though it seemed incredible that the 
wild type of one of the most familiar garden plants should have its home at the very gate as it were of Yokohama and remain unrecognized by any botanist. However, such are the facts. At other times during 1917 and again the following year I prosecuted my investigations so as to leave no possible doubt on the subject. Exigencies of work have prevented the earlier publication of these facts.

The introduction of this plant into Europe seems to have been from China through Sir Joseph Banks early in 1789. In the Kew Bulletin for 1891 there appears a historical account of Kew and on page 305 it is stated that Banks introduced "the first Hydrangea hortensis to Kew about the beginning of 1789 for the inspection of the curious. It had begun to flower in the Custom House and its green petals were a puzzle to the botanists of the day. The next day he exhibited it at his house in Soho Square from whence it was removed and lived in Kew, the parent of its numerous progeny now spread all over Europe.” In the Botanical Magazine xim. under t. 438 it is stated that it "was introduced from China to the royal garden at Kew by Sir Joseph Banks in 1790; it was imported by Mr. Slater about the same time, with whom it is said to have first flowered in this country." Jussieu, in basing the genus Hortensia on the plant, calls it the Rose of Japan. Lamarck gives the same vernacular and on the authority of Commerson says it is cultivated in the Isle of France (Mauritius) and that it came originally from Japan and China. The first illustration published of the plant that I have been able to find is by Buchoz in his Fleurs de la Chine pt. 1, t. 45 (1776) with Chinese characters, evidently a copy of a Chinese drawing and rather crude. The first mention of this plant in western literature is by Kaempfer in his Amoenitatum Exoticarum Fasc. v. page 854 (1712) under the vernacular name of "Sijo, vulgo Adsai, it. Ansai \& Adsikii." According to Smith there is (or was) a drawing of Kaempfer's under this name in the British Museum. In Japan today it is known as Temari-bana.

As a cultivated plant I am familiar with this Hydrangea in many parts of China from the coast to the extreme west and in all the warmer parts of Japan. Where there is iron in the soil the flowers are always blue. Cultivated by florists especially are many fine forms of this Hydrangea chiefly raised in France and referred to as French hybrids. From Messrs. Dreer \& Co. of Riverton, New Jersey, I have received a set consisting of forty named garden forms but I can find no signs of hybridity in any of these. Apparently the word hybrid has been loosely used though I have no doubt crossings have been made with forms having only a few sterile ray-flowers all of which are referable to the var. normalis Wils. In none can I find any signs of the $H$. serrata De Candolle and its forms, the other Japanese species which has been so thoroughly confused with $H$. macrophylla and its varieties. 
A form much cultivated is:-

Hydrangea macrophylla f. otaksa Wilson, n. comb.

Hydrangea Otaksa Siebold \& Zuccarini, Fl. Jap. I. 105, t. 52 (1840).-Van Houtte in Fl. des Serr. xvir. 35, tt. 1732-33 (1867-68).--Neumann in Rev. Hort. 1868, 452, t.

Hydrangea Hortensia var. Otaksa A. Gray in Mem. Am. Acad. n. ser. vi. 312 (Bot. Jap.) (1857).-Maximowicz in Mém. Acad. Sci. St. Pétersb., sér. 7, x. no. xvi. 14 (Rev. Hydrang. As. Or.) (1867).-Hemsley in Garden, x. $266(1876)$.

Hydrangea japonica s. Otaksa Regel in Gartenfl. xv. 290 (1866).

Hydrangea Hortensis 1. Otaksa Franchet \& Savatier, Enum. Pl. Jap. I. 152 (1875).--Nicholson, Dict. Gard. II. 163 (1887).

Hydrangea opuloides d. Otaksa Dippel, Handb. Laubholzk. IIr. 323 (1893).Schneider, Ill. Handb. Laubholzk. I. 392 (1905).-Matsumura, Ind. Pl. Jap. II. pt. 2, 180 (1912).--Rehder in Bailey, Stand. Cycl. Hort. III. 1621, fig. 1933 (1915).

This form, characterized by its globose heads of sterile pink or blue flowers, is one of the most popular with florists in America and Europe. Siebold's name "Otaksa" is not used in Japan today and Japanese scholars fail to understand its derivation. A number of named forms are in cultivaiion including one with pure white flowers and known as $\mathrm{Hy}$ drangea "Thomas Hogg."

Very similar to the above is:-

Hydrangea macrophylla f. Veitchii Wilson, n. name.

Hydrangea Hortensia var. japonica rosea Bean in Garden, L. 122, t. 1079 (1896); not H. japonica var. rosea S. \& Z.

Hydrangea hortensis var. rosea M. H. in Gartenwelt, vir. 582, t. (1903).Grignan in Rev. Hort. 1904, 544, t.

Hydrangea Hortensia var. rosea J. H. Veitch, Hortus Veitchii, 368 (1906).

A garden form with deep rose-pink sterile flowers introduced from Japan into England by Charles Maries in 1880.

A form with black-purple shoots is:-

Hydrangea macrophylla f. mandschurica Wilson, n. comb.

Hortensia nigra Carrière in Rev. Hort. 1880, 180.

Hydrangea nigra Carrière, l. c., as a synonym.

Hydrangea Mandschurica nova Baumann apud Carrière, l. c., as a synonym. Hydrangea ramis pictis Haage \& Schmidt apud Carrière, l. c., as a synonym.

Hydrangea opuloides mandschurica h. apud Dieck, Haupt-Cat. Zoeschen, 42 (1885).

Hydrangea ramulis nigris Hort. ex Dieck, l. c. as a synonym.

Hydrangea mandschurica Koehne, Deutsch. Dendr. 187 (1893).

Hydrangea opuloides e. cyanoclada Dippel, Handb. Laubholzk. III. 323 (1893).Rehder in Bailey, Stand. Cycl. Hort. III. 1621 (1915).

Hydrangea hortensis var. nigra Rehder in Bailey, Cycl. Am. Hort. Ir. 785 (1900).-Bean, Trees \& Shrubs Brit. Isl. I. 625 (1914).

Hydrangea cyanoclada Hort. ex Bean, Trees \& Shrubs Brit. Isl. I. 625 (1914), as a synonym.

A curious form with the young shoots dark purple, almost black, and rose-colored flowers most of which are sterile. The name "mandschurica" is utterly misleading, the plant having nothing to do with Manchuria. This form is cultivated (No. 5285) in the Arnold Arboretum and lives 
through the winter in a sheltered situation but never flowers. The H. Hortensia \&. ramis atropurpureis K. Koch (Hort. Dendr. 106 [1853]) probably belongs here.

A form with double flowers is:-

Hydrangea macrophylla f. Domotoi Wilson, n. comb.

Hydrangea Domotoi K. in American Florist, 1923, 861.

Hydrangea Otaksa Domotoi Hort. Dreer \& Sons.

The flowers of this form are all sterile and double, lavender to blue in color. It is said to have originated as a sport from f. Otaksa and is recognized here as the type of a race with double flowers.

The phylogenetic type may be named:-

Hydrangea macrophylla var. normalis Wilson, n. var.

JAPAN: Hon d o, Oshima Island, E. H. Wilson, No. 8197, March 29, 1917; same locality, H. Suzuki, No. 8197a, July, 1917; Boshu peninsula, between Hojo and Kanaya, E. H. Wilson, No. 8207, April 11, 1917; Hachijo Island, E. H. Wilson, No. 8383, May 6, 1917.

This is the wild type and is distinguished by its flat corymb of hermaphrodite flowers with a few outer sterile pink ray-flowers each from 3 to $5 \mathrm{~cm}$. in diameter. The fruit is stout, yellow-brown and erect, narrow-ovoid, 6-8 mm. long, 3-4 mm. wide, ribbed, crowned by 3 diverging woody styles from 1-3 mm. long; pedicels rigid $7-10 \mathrm{~mm}$. long. The habit, the character of the shoots and the shape and texture of the leaves are all similar to those of the sterile form. The number of ray flowers with petaloid sepals is variable and so, too, is their size, and their color is of varying shades of pink to rosy-red, occasionally bluish or white.

This is a littoral plant abundant on the coasts of Oshima or De Vries' Island and the Boshu peninsula on the east coast of central Hondo and not far from the port of Yokohama. It is also plentiful on Hachijo Island, a volcanic island south of Oshima, and on Aogashima, another island just south of Hachijo. My friend, Dr. T. Nakai, informs me that he has found it wild on North Sulphur Island which is south of the Bonin Islands; also that it grows on the seacoast of Idzu and Sagami in central Hondo. I found the plant first in fruit and young foliage in March 1917 on Oshima and in the July following, my friend, H. Suzuki, collected for me flowering material. In the autumn of the same year I obtained seeds from which plants were raised and are now growing in this Arboretum. On Boshu and Hachijo I saw this plant growing in great quantity and that it is truly indigenous in these places there can be no doubt. Should anyone be disposed to question this as to Boshu and Oshima owing to their proximity to such a centre of culture as Tokyo I do not see how they can question Hachijo which is an out-of-the-way, sparsely inhabited island strewn with blocks of lava. Under the old regime when the Emperor lived in Kyoto and the Shogun in Tokyo, Hachijo was used as a penal settlement. Nevertheless, it is extraordinary that the identity of this plant as the wild parent of the familiar garden Hydrangea with globose 
heads of sterile flowers should have remained unsuspected, at least so far as books are concerned, for I have searched high and low and can find no suggestion of it. Charles Maries in 1879 visited Oshima and there collected bulbs of Lilium auratum var. platyphyllum Baker. He must have seen this wild Hydrangea but I can find no record of its being mentioned by him although be did introduce two fine forms of Hydrangeas which are named Mariesii and Veitchii. Different Japanese botanists have visited Oshima and the other stations of the plant, but I cannot find that any one of them has identified this or saw in it anything significant, although Dr. T. Nakai informs me that he, for some time past, has been aware of its identity, but has not published his conclusions. The wild plant is a shrub from 1 to $3 \mathrm{~m}$. tall with many stems forming a broad bush which occurs either singly or many together making a dense thicket. It grows right on the edge of the foreshore under the full influence of the sea and also inland among volcanic detritus, but all parts of the localities in which I know this plant to be wild are strongly influenced by the sea. The plant is in fact simply and solely a littoral plant, an important point to be remembered when you come to discuss Hydrangea serrata DC., with which it is almost inextricably confused. The giving of a special varietal name to the wild plant may conduce to clearness though there is nothing to distinguish it from such garden forms as Siebold's $H$. japonica (which by the way is not the plant known in gardens today by this name) except its entire petaloid sepals which may or may not be a constant character. The Japanese name of this plant is Gaku or Gaku-bana.

A form with blue flowers is:-

Hydrangea macrophylla var. normalis f. coerulea Wilson, n. comb.

Hydrangea Belzonii Siebold \& Zuccarini, Fl. Jap. I. 109, t. 55 (1840).

Hydrangea Japonica var. caerulea Hooker in Bot. Mag. LxxIr. t. 4253 (1846).

Hydrangea Hortensia $\beta$. coerulea K. Koch, Hort. Dendr. 106 (1853).

Hydrangea japonica \&. coerulescens Regel in Gartenfl. xv. 290 (1866).

Hydrangea Hortensia $\gamma$. Belzonii Maximowicz in Mém. Acad. Sci. St. Pétersb. sér. 7, x. no. Xvi. 14 (Rev. Hydrang. As. Or.) (1867).-Hemsley in Garden, x. $266(1876)$.

Hydrangea opuloides e. Belzonii Dippel, Handb. Laubholzk. III. 322 (1893).Rehder in Bailey Stand. Cycl. Hort. III. 1621 (1915).

Hydrangea hortensis var. Belzonii Nakai in Tokyo Bot. Mag. xxxi (196)(1917).

Hydrangea opuloides var. japonica f. coerulea Rehder in Jour. Arn. Arb. III. $43(1922)$.

This form is distinguished by its deep blue hermaphrodite flowers and blue or white sterile ray-flowers. The leaves are ovate-elliptic to obovate. As Rehder points out this is a very hardy form.

Siebold figures for his $H$. Belzonii a plant with obovate leaves in whorls of three and states in the text that the leaves are ternate or rarely opposite. I have seen no specimens with leaves so arranged though doubtless it does occur on some cultivated plants. Siebold also states that the ray-flowers are very numerous, being from 12 to 15 , and he figures a fragment of an inflorescence in which all the flowers are sterile. A co-type in the Gray Herbarium of the plant referred by Maximowicz to his var. Belzonii has 
opposite leaves; another specimen in the same herbarium from the Herb. Lugd.-Batav. and named $H$. Belzonii has opposite, ovate leaves and nearly ripe fruits. The Japanese name Oho-Azisai given by Siebold and Zuccarini merely signifies "Large Azisai" and is virtually meaningless.

Another form is :-

Hydrangea macrophylla var. normalis f. azisai Wilson, n. comb.

Hydrangea Azisai Siebold in Nov. Act. Acad. Leop.-Carol. xiv. pt. 2, 689 (Syn. Hydrang.) (1829).-De Candolle, Prodr. Iv. 666 (1830).- Siebold \& Zuccarini, Fl. Jap. I. 104, t. 51 (1840).

Hydrangea Hortensia var. Azisai A. Gray in Mem. Am. Acad. n. ser. vi. 312 (Bot. Jap.) (1857).-Maximowicz in Mém. Acad. Sci. St. Pétersb., sér. 7, x. no. XVI. 14 (Rev. Hydrang. As. Or.) (1867).-Hemsley in Garden, x. 266 (1876).

Hydrangea Hortensis \&. Azisai Franchet \& Savatier, Enum. Pl. Jap. I. 152 (1875).

Hydrangea opuloides b. Azisai Dippel, Handb. Laubholzk. III. 322 (1893).-Schneider, Ill. Handb. Laubholzk. I. 392 (1905).--Rehder in Bailey, Stand. Cycl. Hort. III. 1621 (1915).

This is a Japanese garden plant distinguished by its ovate to ellipticovate leaves, and pale blue to white sterile ray-flowers on very long (2.5 $\mathrm{cm}$.) pubescent pedicels. The vernacular name Azisai is by no means restricted to this particular form and is in fact more generally applied to $H$. serrata DC. which is common on the mountains throughout the length and breadth of Japan.

A form with white ray-flowers is:-

Hydrangea macrophylla var. normalis f. macrosepala Wilson, n. comb. Hydrangea japonica s. macrosepala Regel in Gartenfl. xv. 290, t. 520 (1866). Hydrangea opuloides f. macrosepala Dippel, Handb. Laubholzk. III. 323 (1893).--Rehder in Bailey, Stand. Cycl. Hort. III. 1621 (1915).

Hydrangea hortensis var. macrosepala Rehder in Bailey, Cycl. Am. Hort. II. $785(1900)$

This garden form is characterized by its white, toothed, sterile rayflowers.

A form with pink ray-flowers is:-

Hydrangea macrophylla var. normalis f. rosea Wilson, n. comb.

Hydrangea japonica Siebold in Nov. Act. Acad. Leop.-Carol. xıv. pt. 2, 689 (Syn. Hydrang.) (1829).-De Candolle, Prodr. Iv. 666 (1830).- - Siebold \& Zuccarini, Fl. Jap. I. 106, t. 53 (1840) in part.

Hydrangea japonica var. rosea Siebold \&; Zuccarini, Fl. Jap. I. 107 (in text) (1840).

Hydrangea japonica $\alpha$. typica Regel in Gartenfl. xv. 289 (1866).

Hydrangea Hortensia $\beta$. japonica Maximowicz in Mém. Acad. Sci. St. Pétersb., sér. 7, x. no. xvi. 14 (Rev. Hydrang. As. Or.) (1867).-Hemsley in Garden, x. $266(1876)$.

Hydrangea Hortensis 8. Japonica Franchet \& Savatier, Enum. Pl. Jap. I. 151 (1875).--Nicholson, Dict. Gard. II. 162 (1887).

Hydrangea opuloides var. b. japonica Schneider, Ill. Handb. Laubholzk. I. 392 (1905).-Matsumura, Ind. Pl. Jap. II. pt. 2, 179 (1912), in part.-Rehder in Bailey, Stand. Cycl. Hort. III. 1621 (1915). 
This form has pink, more or less toothed ray-flowers, otherwise it is very similar to the wild form. Of the vernacular names cited by Siebold \& Zuccarini only "Gakuso" is applicable to this plant. In gardens today the plant generally cultivated under the name of $H$. japonica is not Siebold's plant but is the form rosalba of $H$. serrata DC. which is the "Benikaku" of the Japanese. Siebold and Zuccarini applied this vernacular name among others to their $H$. japonica and it is probably this that has lead Japanese botanists astray in the identification of Siebold's species.

A fine garden form is:-

Hydrangea macrophylla var. normalis f. Mariesii Wilson, n. comb.

Hydrangea Hortensia var. Mariesii Bean in Garden, LIv. 390, t. 1196 (1898).J. H. Veitch, Hortus Veitchii, 368 (1906).

Hydrangea hortensis var. Mariesii Bean, Trees \& Shrubs Brit. Isl. I. 625 (1914). Hydrangea opuloides var. Mariesii Rehder in Bailey, Stand. Cycl. Hort. III. 1621 (1915).

A garden form introduced into England from Japan in 1880 by Charles Maries characterized by its large, sterile, rose-pink ray-flowers which measure from 7 to $8 \mathrm{~cm}$. across and are entire or sparsely toothed.

A form with variegated leaves is:-

Hydrangea macrophylla var. normalis f. maculata Wilson, n. comb.

Hydrangea hortensis var. maculata Blume, Bijdr. 920 (1826).

Hydrangea japonica fol. albo-variegatis van Houtte in Fl. des Serr. vir. 139, t. $696(1851-52)$.

Hydrangea Hortensia 8. maculata K. Koch, Hort. Dendr. 106 (1853).

Hydrangea japonica s. variegata Regel in Gartenfl. xv. 290 (1866).

Hydrangea hortensis variegata Nicholson, Dict. Gard. II. 163 (1887).

Hydrangea opuloides var. variegata Rehder in Bailey, Stand. Cycl. Hort. III. $1622(1915)$.

Distinguished by the white edging of the leaves. This form was in cultivation at Batavia at a very early date, having been introduced directly from Japan. Other garden forms with vari-colored leaves are known as f. tricolor, nivalis and roseo-marginata.

Hydrangea serrata De Candolle, Prodr. Iv. 15, 666 (1830).-Dippel, Handb. Laubholzk. III. 325, fig. 173 (1893).-Schneider, Ill. Handb. Laubholzk. 1. 392 (1905).

Viburnum serratum Thunberg, Fl. Jap. 124 (1784).

Hydrangea Thunbergii Siebold in Nov. Act. Acad. Leop.-Carol. xIv. pt. 2, 690 (Syn. Hydrang.) (1829).- Siebold \& Zuccarini Fl. Jap. I. 111, t. 58 (1840).-Maximowicz in Mém. Acad. Sci. St. Pétersb., sér. 7, x. no. xvi. 15 (Rev. Hydrang. As. Or.) (1867).--T. Moore in Gard. Chron. 1870, 1699, fig. 297.-Franchet \& Savatier, Enum. Pl. Jap. I. 153 (1875).-Hemsley in Garden, x. 266 (1876).--Nicholson, Dict. Gard. II. 163 (1887).-Bean, Trees \& Shrubs Brit. Isl. I. 630 (1914).

Hydrangea Hortensis ל. angustata Franchet \& Savatier, Enum. Pl. Jap. I. 151 (1875).

Hydrangea opuloides e. angustata Schneider, Ill. Handb. Laubholzk. I. 392 (1905).—Matsumura, Ind. Pl. Jap. II. pt. 2, 179 (1912), in part.

Hydrangea hortensis var. serrata Rehder in Bailey, Cycl. Am. Hort. II. 785 (1900). 
Hydrangea opuloides var. Thunbergii Makino in Tokyo Bot. Mag. xxvr. 389 (1912)

Hydrangea cyanea Hort. apud Bean, Trees \& Shrubs Brit. Isl. I. 630 (1914).

Hydrangea opuloides var. serrata Rehder in Bailey, Stand. Cycl. Hort. III. 1621 (1915).

Hydrangea persicifolia Hort. ex Herb. Arnold Arboretum.

JAPAN. Kyushu: prov. Satsuma, Kirishima, alt. 100-1000 m., Z. Tashiro, October, 1917; Shikoku, prov. Tosa, Shiraga-yama, alt. 1100 m., E. H. Wilson, No. 1720, November 22, 1914; Nanokawa, K. Watanabe, July, 1888 (Herb. Gray). Hon do: prov. Settsu, Arima, A. Henry (No. M. 83); prov. Yamashiro, Kyoto, June 24, 1911; prov. Shinano, Otake-gawa, alt. 1000 m., E. H. Wilson, No. 7767, November 1, 1914; Norikura, U. Faurie, No. 6859, August 30, 1905; Ogawa, J. G. Jack, September 4, 1905; prov. Sagami, Komagatake, alt. 2000 m., U. Faurie, No. 6862, July, 1905; Miyanoshita, C. S. Sargent, August 25, 1892; same locality, Drs. Fred \& Charlotte Baker, June 18, 1914, Hakone, C. Maximowicz, 1862 (Herb. Gray); prov. Musashi, Mitsumine-san, E. H. Wilson, No. 6963, June 8, 1914; same locality, June 24, 1911; Mt. Buko, K. Sakurai, June 25, 1911; prov. Kai, Jizo-gatake, U. Faurie, July, 1903; prov. Kozuke, Karuizawa, alt. 1000 m., E. H. Wilson, Nos. 7419, 7146, August 1, 1914; prov. Shimotsuke, Nikko region, alt. 1600-2000 m., E. H. Wilson, June 28, 1914; Lake Chuzenji, J. G. Jack, August 10 and 12,1905 . Without locality ex Herb. Lugd. Batav. as Hydrangea Buergeri and H. japonica (Herb. Gray).

KoreA: Quelpaert Island, alt. 600 m., E. H. Wilson, No. 9402, October 30, 1917; same place and collector, No. 9402a, November 6, 1917; same locality, U. Faurie, Nos. 355, 359, 1653, October, 1906, July, 1907; same locality, E. Taquet, No. 4240, July 15,1910 .

Cultivated: Arnold Arboretum, July 20, 1890, July 9, 1897, Nos. 519, 519-1, 3269; July 6, 1923, E. H. Wilson, No. 7621; Kew Gardens, G. Nicholson, No. 2900, July 13, 1882; Hort. Muskau, September 15, 1895, ex Herb. Zabel, No. 1881; Botanic Garden, Sapporo, Hokkaido, E. H. Wilson, No. 7303, July 29, 1914; same garden, S. Arimoto, September 7, 1903 (Herb. Gray).

Shrub $1-2.5 \mathrm{~m}$. tall (usually $1-1.5 \mathrm{~m}$.) with erect slender stems, glabrous or pubescent the first year, clothed with thin brown-purple scaling bark. Leaves membranous, dull dark green, lanceolate or elliptic to ovate, rarely broadest above the middle, without petiole $5-10 \mathrm{~cm}$. long, $1.5-5 \mathrm{~cm}$. wide, acuminate; the base cuneate, rarely abruptly so, sometimes attenuate and oblique, finely or coarsely serrate, often entire at base; the teeth terminating in gland-tipped mucro, sparsely clothed with appressed soft pubescence on both surfaces, with small axillary tufts of curled hairs on the lower surface; midrib with short curled hairs sometimes on upper surface only; petiole 1-2.5 cm. (sometimes $5 \mathrm{~cm}$.) long, usually slender. Flowers blue or white in flat or slightly convex corymbs, $5-10 \mathrm{~cm}$. across with 4 or 5 white, blue or pinkish petaloid, orbicular, ovate or lanceolate, rounded, obtuse or more rarely acute sepals. Capsule thin-walled, ovoid, subglobose, $2-4 \mathrm{~mm}$. long, on a slender pedicel and tipped by 3 short diverging styles.

This is a common woodland plant on the mountains from the extreme south of Japan to southern Hokkaido; it is also plentiful on the Korean island of Quelpaert and on the mainland as far north at least as Chiri-san. At the northern limits of this species the plant is found at sea-level but always in cool situations. It loves woodland soil and shade and it is only at high altitudes and at its northern limits that it grows in open places. The plant varies greatly in the size, shape and dentation of the 
leaves and in degree of hairiness; the sterile flowers may be blue, white or pinkish and the shape of the petaloid sepals varies from nearly round to lance-shape and either rounded blunt or pointed. It is a hardy plant and I have seen it flourishing in the Botanic Garden in Sapporo, Hokkaido. In this Arboretum it has flowered many times but the plant does not thrive. It has several Japanese names such as Hosoba-amacha, Yamaajisai and Sawa-ajisai but the one I heard most usually applied to this plant is Yama-ajisai which may be interpreted Mountain Hydrangea.

As they grow wild no two species could be more distinct than the littoral $H$. macrophylla var. normalis Wils. and the woodland $H$. serrata DC., but in herbaria it is not easy to distinguish between dried specimens of the extreme forms of each and this has had much to do with the hopeless confusion between them which obtains in books. The relatively thick, fleshy, shining green leaves of the former and the thin, dull dark green leaves of $H$. serrata readily distinguish the species. The woodland plant is in every way a less vigorous plant than its relative of the seashore whose leaves are usually broadest above the middle and rarely so in the woodland species. From Siebold all authors have recognized under various names these two species as distinct and those familiar with the living plants have never hesitated in the matter but the forms of the dull green membranous-leafed species have been confused under $H$. macrophylla. The synonymy shows this very clearly and perhaps is more expressive than any lengthy explanation could possibly be.

In Thunberg's Herbarium the three specimens named Viburnum serratum $\gamma, \delta$, and $\varepsilon$ are the type of the species.

A form with large leaves is:-

Hydrangea serrata f. acuminata Wilson, n. comb.

H. acuminata Siebold \& Zuccarini, Fl. Jap. I. 110, tt. 56, 57, fig. 1 (1840).Carriere in Rev. Hort. 1874, 91, t.-Bean, Trees \& Shrubs Brit. Isl. I. 625 (1914).

H. Buergeri Siebold \& Zuccarini, Fl. Jap. I. 111, t. 57, fig. 2 (1840).

$H$. Hortensia $\alpha$. acuminata Maximowiczii in Mém. Acad. Sci. St. Pétersb., sér. 7 , x. no. Xvi. 13 (Rev. Hydrang. As. Or.) (1867), not A. Gray in Sched. Pl. Wright.-Hemsley in Garden X. 265 (1876).

H. Hortensis $\alpha$. acuminata Franchet \& Savatier, Enum. Pl. Jap. I. 150 (1875).Rehder in Bailey, Cycl. Am. Hort. II. 785 (1900).

H. opuloides var. acuminata Dieck, Haupt-Cat. Zoeschen, 42 (1885).-Dippel, Handb. Laubholzk. III. 323 (1893).-Schneider, Ill. Handb. Laubholzk. I. 391, fig. $2500^{-t}$ (1905).--Rehder in Bailey, Stand. Cycl. Hort. III. 1621 (1915).

H. opuloides var. angustata Matsumura, Ind. Pl. Jap. II. pt. 2, 179 (1912), in part, vix Franchet \& Savatier.

H. opuloides var. acuminata f. Bürgeri Purpus in Moeller's Deutsch. Gärtn.Zeit. xxxir. 41, fig. (1917).

JAPAN. K y u shu : Tsu-shima Island, C. Wilford, 1859 (Herb. Gray), prov. Satsuma, Mt. Kirishima, alt. 100-1000 m., Z. Tashiro, June 24, July 29, 1917; prov. Osumi, Nishi-kirishima, E. H. Wilson, No. 6244, March 3, 1914. H on do: prov. Uzen, Adzuma-san, alt. 600-11000 m., E. H. Wilson, No. 7212, July 19, 1914; prov. Ugo, Chokai-san, E. H. Wilson, No. 7173, October 14, 1914; prov. 
Mutsu, Lake Towada, E. H. Wilson, No. 7621, October 5, 1914; Hakkoda-yama, alt. 1000-1500 m., E. H.Wilson, No. 7118, July 6, 1914. H o k k a i d o : prov. Oshima, Hakodate, C. Maximowicz, 1861 (Herb. Gray); prov. Shiribeshi, Shiribeshi-san, alt. 1000 m., E. H. Wilson, No. 7298, July 27, 1914; prov. Ishikari, Moiwa-dake, ex Herb. Sapporo Agric. College, July 29, 1891; same locality, C. S. Sargent, September 17, 1892; same locality, S. Arimoto, September 24, 1903, (Herb. Gray); Yubari, E. Tokubuchi, August 11, 1893 (Herb. Gray).

Korea: Quelpaert Island, E. H. Wilson, No. 9402, November 2, 1917; same locality, June 25, 1908, E. Taquet, Nos. 811, 2886, 2887, June, 1909, July, 1909.

Cultivated: Arnold Arboretum, July 9, 1904 (No. 4710); Japan, Hokkaido, Botanic Garden, Sapporo, C. S. Sargent, September 16, 1892.

This form may be distinguished by its larger caudate-acuminate leaves 9 to $18 \mathrm{~cm}$. long and $5-12 \mathrm{~cm}$. wide, though it is scarcely worth a distinctive name. It has a similar distribution to the type but is more common in the northern part of Hondo and in Hokkaido. The sterile ray-flowers are usually blue but not invariably so on the wild plants. In books A. Gray is cited as the first to unite Siebold's $H$. acuminata with $H$. Hortensia DC. and there is no doubt Gray intended to do this but the specimens he so named in the Gray Herbarium belong to a different species recently named H. Kawagoeana Koidzumi (in Tokyo Bot. Mag. xxxı. 138 [1918]). The material in the Gray Herb. consists of one sheet of four fragments each in flower and bears two labels. One label says, "Loo-choo Islands, Cleopatra Island, T. Small”; the other "Simoda, Japan, C. Wright coll.” The material is obviously all from the same plant and I am sure came from Cleopatra Island and not from Simoda. The firm purple-brown bark at once distinguishes this plant from either Siebold's or De Candolle's species.

Another form is:-

Hydrangea serrata f. pubescens Wilson, n. comb.

Hydrangea Hortensis $\beta$. pubescens Franchet \& Savatier, Enum. Pl. Jap. r. 151 (1875), not H. pubescens Decaisne.

Hydrangea opuloides i. sinensis Dippel, Handb. Laubholzk. III. 324, fig. 172 as $H$. sinensis (1893).

Hydrangea opuloides d. pubescens Schneider, Ill. Handb. Laubholzk. I. 392 (1905).-Matsumura, Ind. Pl. Jap. II. pt. 2, 180 (1912).

Hydrangea sinensis Hort. Simon Louis.

JAPAN. Hokkaido: prov. Oshima, Hakkodate, Dr. M. Albrecht, (Herb. Gray).

Korea: Quelpaert Island, October, 1906, U. Faurie, No. 357; same locality, E. Taquet, No. 810, July, 1908.

Cultivated: Arnold Arboretum, No. 2443-2; Hort. Simon Louis, 1888, Herb. H. Zabel.

This pubescent form with ovate to ovate-elliptic, caudate-acuminate leaves is fairly distinct though very close to the form acuminata. The sterile ray-flowers are pink and white and the fertile flowers blue. The principal veins on the underside are bearded with soft appressed and spreading hairs; tho base of the leaf is rounded and abruptly cuneate or narrow and cuneate. The Japanese name of this form is Iwa-gaku. 
A form with flowers of various colors is:-

Hydrangea serrata f. rosalba Wilson, n. comb.

Hydrangea japonica Siebold \& Zuccarini, Fl. Jap. I. 106 (1840), in part.Lindley in Bot. Reg. xxx. t. 61 (1844).-Paxton, Mag. Bot. xir. 199, t. (1846).-Bean, Trees \& Shrubs Brit. Isl. I. 626 (1914).

Hydrangea japonica rosalba Van Houtte in Fl. des Serr. xvi. 75, tt. 1649-50 (1865-66).-Carrière in Rev. Hort. 1866, 432, t.-Regel in Gartenfl. xv. 290 (1866).

Hydrangea japonica $\beta$. Lindleyi Regel in Gartenfl. xv. 289 (1866).

Hydrangea opuloides $\alpha$. roseo-alba Dippel, Handb. Laubholzk. III. 324 (1893).

Hydrangea Hortensis var. Lindleyana Nicholson in Garden, XLVI. 466 (1894).

Hydrangea Lindleyana Nicholson in Garden, XLvi. t. 990 (1894).

Hydrangea hortensis var. rosalba Rehder in Bailey, Cycl. Am. Hort. II. 785 (1900).

Hydrangea opuloides var. Lindleyana Rehder in Bailey, Stand. Cycl. Hort. III. 1621 (1915).

Hydrangea opuloides var. rosalba Rehder in Mitt. Deutsch. Dendr. Ges. xxiv. 220 (1915).

Cultivated: Arnold Arboretum (Nos. 516, 516-1, 517, 517-1, 521, 521-1, 522-1, 2210-1, 2442, 2444); Hort. Bot. Gard. Washington, A. Rehder, June 27, 1900; Hort. Kew, G. Nicholson, Nos. 1777, 1784, 1789, July 19, 1880; Hort. Bot. Gard. Kiel, B. Graef, No. 3557, 1897. Japan; Hort. Sakurai, K. Sakurai, May 12, 1906; Tokyo, K. Miyabe, June 10, 1882.

In this form the leaves are somewhat pubescent on the underside and on the upper surface of the midrib especially at the base, and vary in shape from obovate to ovate-elliptic. The sterile ray-flowers may be white or pink or in fading may change from one color to the other. The petaloid sepals may be deeply or sparingly toothed, or they may be entire. It is a variable and very common form and is often cultivated under the erroneous name of $H$. japonica. There are also very many garden forms of this plant; indeed, most of them which have been raised in France and have dull green leaves have been derived from it; such is $H$. "Impératrice Eugénie" Carrière in Rev. Hort. 1868, 469, t.

A form with numerous sterile flowers is:

Hydrangea serrata var. stellata Wilson, n. comb.

Hydrangea Sitsitan Siebold in Nov. Act. Acad. Leop.-Carol. xIv. pt. 2, 692 (Syn. Hydrang.) (1829).-De Candolle, Prodr. Iv. 666 (1830).

Hydrangea stellata Siebold \& Zuccarini, Fl. Jap. I. 112, t. 59 (1840).-Regel in Gartenfl. xv. 291 (1866).-Bean, Trees \& Shrubs Brit. Isl. I. 626 (1914).

Hydrangea stellata $\beta$. prolifera Regel in Gartenfl. xv. 291, t. 521 (1866).Nicholson, Dict. Gard. II. 163 (1887).

Hydrangea Hortensia $\eta$. stellata Maximowicz in Mém. Acad. Sci. St. Pétersb., sér. 7, x. no. xvi. 14 (Rev. Hydrang. As. Or.) (1867).-Hemsley in Garden x. $266(1876)$.

Hydrangea Hortensis 3. stellata Franchet \& Savatier, Enum. Pl. Jap. I. 152 (1875).

Hydrangea opuloides h. stellata Dippel, Handb. Laubholzk. III. 324 (1893).-Schneider, Ill. Handb. Laubholzk. I. 392 (1905).--Matsumura, Ind. Pl. Jap. II. pt. 2, 180 (1912).--Rehder in Bailey Stand. Cycl. Hort. III. 1622 (1915).

Hydrangea opuloides var. prolifera Rehder in Bailey, Stand. Cycl. Hort. III. $1622(1915)$.

This is a sterile form with numerous petaloid sepals, pink rose or white in color and ovate to lanceolate in shape. Siebold records it as cultivated 


\section{$2 \mathrm{BHL}$ Biodiversity Heritage Library}

Wilson, Ernest Henry. 1923. "The Hortensias Hydrangea macrophylla DC. and Hydrangea serrata DC." Journal of the Arnold Arboretum 4(4), 233-246. https://doi.org/10.5962/p.317979.

View This Item Online: https://www.biodiversitylibrary.org/item/33584

DOI: https://doi.org/10.5962/p.317979

Permalink: https://www.biodiversitylibrary.org/partpdf/317979

\section{Holding Institution}

Missouri Botanical Garden, Peter H. Raven Library

\section{Sponsored by}

Missouri Botanical Garden

\section{Copyright \& Reuse}

Copyright Status: Public domain. The BHL considers that this work is no longer under copyright protection.

This document was created from content at the Biodiversity Heritage Library, the world's largest open access digital library for biodiversity literature and archives. Visit BHL at https://www.biodiversitylibrary.org. 